Marmara Üniversitesi Siyasal Bilimler Dergisi • Marmara University Journal of Political Science • Cilt 5, Sayı 2, Eylül 20I7, ISSN 2147-6934, ss. 245-262 • DOI: xxxx

\title{
Turkey: In the Midst of Crisis, Between Liberal Utopia and Keynesian Regulation
}

\author{
Türkiye'de Ekonomik Krizler: Liberal Ütopyadan Keynesci \\ Uygulamalara
}

Özgür ÜŞENMEZ*

\begin{abstract}
As Turkey's growth numbers signalled negative news about the near future, possible economic remedies to solve an upcoming economic slowdown have been discussed. In this article by looking at the financial and banking sector performance of the country during 2001 local and 2008 global crisis, I tried to compare two mainstream strands of theory, i.e. liberal and Keynesian approaches to the economic crisis. It seems like the country has experienced a neo-liberal, unregulated financial episode until 2001 crisis, while in post-2001 period we have witnessed more regulatory and Keynesian financial remedies which were successful to save the country from more harmful effects of the Great Recession. Those Keynesian style regulations were mainly inspired from the effects of changes within the governing style of international financial institutions. But in the final section of the analysis, through pointing out the potential triggers for another economic crisis, this article argues that though Keynesian solutions are more logical and helpful in alleviating the symptoms of crisis, they could not make Turkey crisis-free. High current account deficits, persistent inflation, adamant unemployment and insufficient domestic production in the face of rising imports, all of these can be classified as the symptoms of the still crisis prone economic structure in the country. Then, other, more radical alternatives should be on the agenda for a better future.
\end{abstract}

Keywords: Keynesian, Neo-Liberal, Turkey, Crisis

$\ddot{\mathbf{O z}}$

Türkiye’de durağan seyreden büyüme rakamları, yakın gelecekte büyümenin nasıl canlandırılabileceği tartışmalarının ana konusu. Özellikle 90lı yıllarını ve 2000'lerin başlarını ülkeyi derinden sarsan ekonomik krizlerle geçirmiş bir toplumda potansiyel krizlerin nasıl önlenebileceği tartışmaların önemini daha da artırmakta. Bu çalışmada ise 2001 ve 2008 'deki ekonomik kriz evrelerinde ülkenin bankacılık ve finansal sektör performansı üzerinden liberal ve Keynesçi akımların ekonomik modelleri inceleniyor. Türkiye 2001 yılı ortalarına kadar Özal ve Çiller-Demirel yıllarında oluşturulmuş daha serbest ve düzensiz bir liberal finans sistemi içindeyken, 2001 sonrası Keynesçi

* Lecturer Dr., Marmara University Faculty of Political Science, Department of Political Science and International Relations,ozgurusenmez@hotmail.com 
sayılabilecek finansal düzenlemeler ülkeyi 2008 krizinin şiddetli etkilerinden korumada yardımcı olmuştu. Bu başkalaşımın sebeplerinden biri Dünya Bankası ve IMF gibi kuruluşlardaki mantalite değişikliğiydi. 2000'li yılların ortalarında Dünya Bankasındaki eleştirilerin baş ismi Stiglitz’in fikirlerine yakın Kemal Derviş'in Türkiye'deki programı yönetmesi, Keynesyan etkiyi güçlendirecekti. Fakat makalenin son bölümünde dış kaynaklı krizleri tetikleyebilecek mekanizmaların gösterdiği gibi Keynesçi finansal düzenlemeler krizin etkilerini azaltmakta başarılı olsa da Türkiye’yi tamamen potansiyel krizlerden muaf hale getirmiyor. Kronik cari açıklar, yüksek seyreden enflasyon, inelastik yapıdaki işsizlik rakamları ve ithalatı karşılamada yetersiz yerli üretim, kriz eğilimlerinin ülke ekonomisinde devam ettiğinin başlıca göstergeleri. Bu durumda, başka radikal alternatiflerin de gelecek tasarımlarında yer tutması gerekiyor.

Anahtar Kelimeler: Keynesçi, Neo-Liberal, Türkiye, Kriz

\section{Introduction:}

Since the beginning of the 2008 crisis the main disputes in recession-torn economies and societies regarding possible solutions have revolved, not around an ontological critique of the market economy, but around epistemological arguments that involve Liberals and Keynesians. This dispute entails two distinct points. On the one hand is the liberal notion of sustaining investor confidence through austerity and downsizing the state role in economic decision-making. This stems from the liberal idea, the main proponents of which are Reinhardt, Rogoff et al., that the reason for the crisis was unnecessary government involvement in economy. On the other hand, Keynesians argue that the reason for the crisis was the fundamentalist belief in the wisdom of unfettered markets in allocating resources, and consecutive bubbles largely engendered by that financial profligacy. Therefore, according to Krugman et al., any method that aims to return to sustainable growth should be centered on increasing both regulation and government stimulus efforts.

Since it played a huge role in saving Turkish financial institutions from the harmful effects of the last great crisis, I find the Keynesian regulatory alternative more logical for the presentday ills of the capitalist economy. But the partial regulatory policies of this method failing to solve the more perennial and structural problems of the country, exchange rate volatility, high unemployment and unsustainable current account deficits all point to the possibility of a new crisis erupting. By comparing and analyzing Turkish banking sector performance throughout the two recent significant crises, i.e. 2001 local and 2008 global, this paper will theoretically clarify the above-mentioned idea that the Keynesian regulatory alternative is more amenable in controlling the excesses of market economies. However, the final part of the essay will rest on the argument that the relative success of Keynesians is limited, since like the liberals, they do not understand the inseparability of economic policy from the real social relations of production. On the agenda, then for a stable future economic model, should be serious consideration of Marxian alternatives. 


\section{What is Liberal Utopia?}

In order to explain the main distinctions among liberals and other strands of political economy one has to clarify the utopian vision of liberal economics. From the days of Adam Smith, Friedrich Hayek, Austrian school to Milton Friedman, liberal economics operated around certain assumptions which mainly depended on the smooth mechanics of the invisible hand. That invisible hand is nothing other than the unintentional actions of market participants which allegedly work through assumptions such as perfect competition, efficiency of price mechanism to convey information and fundamental equilibrium of supply and demand. Most liberal pundits concurred that any outside intervention to these efficient market and free trade would distort those factors that were mentioned as assumptions above. Thus, in the world of liberals free-trade and free markets are above societal and political discussions and almost god given technicalities. This utopian vision first encountered its biggest criticism around late 1920's when J. Maynard Keynes lucidly displayed their logical faults in the midst of Great Depression, but 70'crisis of Fordism and Welfare state brought back the liberal doctrine from the shelves this time with a new name neo-liberalism. 30 years after the most world countries one way or another immersed in the rules of markets, 2008 crisis and ensuing recessionary tendencies once again escalated the criticisms towards neo-liberal paradigm. Below I will try to explain why liberal economics and their application is utopia in itself through the arguments of two influential scholars of political economy. J. Maynard Keynes and Karl Polanyi.

Keynes first and foremost argument against the laissez faire economics was that the notions of free enterprise and property rights and the framework in which they existed were socially agreed and not necessarily results of God-given natural rights. Under those conditions individual utilitarian calculations could not be all rational or bring collective benefits at the end either. According to Keynes, since everyone needs other peoples' cooperation in capitalist economy some individual actions may derive from pure self-interest or outright irrational incentives (Keynes, 1925). Furthermore, conditions that worked well for the free market and trade of 19th century could not last forever as the 1920's economic indicators and social patterns signified a totally different circumstance. In here Keynes pointed out the need of liberal theory to update itself to historical changes (Keynes, 1963).

Second issue one comes across the writings of J. Maynard Keynes was his opinions on the factors like uncertainty and risks that underpinned the competition in free markets, for him these are not incentives to a better societal condition on the contrary they can be a source of excessive speculation, unemployment and unproductive investments. In order to divert all savings to real economy someone has to regulate this inherent tendency of markets for increasing volatility and instability. Keynes thought that liberal approach on free trade is too chaotic to achieve desired results, someone especially the state has to intervene and regulate these untamed behaviors. As an extension of these arguments we can also pointed out Keynes' criticism of supply-demand equilibrium as a myth since according to him in a constantly changing environment and conditions, that point at a time is a very rare incident if it ever occurs. Psychology of market 
participants and their swift reactions based on expectations would not permit that kind of smooth transaction between supply and demand. A lot of times state has to coordinate excesses or insufficiencies on both sides of equation and institutions such as central bank is mainly needed to correct those market externalities (Skidelsky, 1992).

Karl Polanyi, wrote just after the Great Depression and through the years of war and destruction, had more fundamental criticisms towards the liberal, free market practice. For him, markets and its competitive logic since 19th century gradually encompassed all human activities and subjected them to dictates of free market utopia. Polanyi argued that three important factors that is crucial for a secure and stable human life, i.e. land, labor and money, were subordinated to the commoditization frenzy of market economy. These three factors throughout the history provide most important substances to reproduction of human societies but after the industrial revolution and market economies' competitive production and consumption became so central in human activities, over accumulation of land through urban sprawl and associated environmental damage occurred (Polanyi, 1944). On the issue of labor, Polanyi pointed out that unemployment, anarchic and insecure structure of labor trade under free markets created stress and depress human psychology as most of the time workers were vulnerable to the industrial power of capitalists. About the usage of money, speculative activities and money hoarding to provide security for future in anarchic free markets would distort the supply and demand. That is a sure way for financial and economic crisis since diverting money from its real function in production towards finance spur more uncertainty to the market economy. For Polanyi, these three factors in human society should not be alienated from their original purpose as their subjugation to exchange value rather than their role for use values in human life would inevitably steer counter response from society itself (Polanyi, 1944).

Polanyi called this societal response against the vagaries of market economy, double movement. In his book, The Great Transformation, main examples that were shown as examples of this counter movement started with British Speenhamland laws, a measure to protect the most vulnerable from the worst effects of fledgling capitalism. With the speed up of industrialization minimum wage laws followed the same pattern (Polanyi,1944). When leading capitalist country U.S. faced the worst consequences of the Great Depression, society undertook New Deal policies. Furthermore, since the end of World war 2 from capital controls of Bretton Woods to rising social welfare states can also be given as examples of this counter movement. In the aftermath of 2008 financial crisis, the current questioning of neo-liberal prescriptions and the logic of markets would verify that another double movement is in preparation.

Throughout this essay in line with above argument while we question the liberal utopia and how Keynesians tried to find remedies, on the last part in Turkish economy the period from 19842001 will be evaluated as a practice of liberal, free market utopia. The period in the wake of 2001 crisis, especially the banking and institutional reforms of Dervis era after 2003 can be considered as Keynesian response, since Kemal Dervis was from the World Bank which was questioning the applicability of neo-liberal adjustment programs under the influence of its chief economist Joseph Stiglitz just after the Asian economic crisis (Stiglitz, 2000). 


\section{The 2008 Global Crisis Liberal-Keynesian Dispute: Liberal View}

As explained before, the reasons for and possible solutions to the deepening global crisis since the collapse of the U.S sub-prime mortgage market have been much discussed among major neoliberal and Keynesian economists. Before getting into their detailed explanatory models, one can see that although Hayek's followers are still assertive in their arguments, Polanyi-style or radical alternatives to existing market relationships have been largely overlooked in the last five years. In the juxtaposition below, I try to outline the rival thoughts within the process of the evolving crisis in both political and economic arenas.

Current neo-classical economists, in line with the mentality of Hayek's methodological individualism, tend to have a blind spot when it comes to any inherent structural problems within capitalist social relationships, and emphasize instead the exogenous shocks or humanmade mistakes as the probable causes of the crisis. Since capitalist markets accurately reflect the behavior of self-interested rational man, and combine this with the ceterus paribus assumptions on perfect competition, the power of price signals, and the recurring equilibrium of demand and supply, there cannot exist an internal crisis tendency associated with market economy. So, how do neo-liberals define the emergence of the 2008 financial crisis? Most stressed excessive government intervention in the housing market: CRA and affordable housing policies forced the government-subsidized Fannie Mae and Freddie Mac to underwrite huge amounts of subprime mortgages, which in turn fed the housing bubble in the U.S. Wallison further argued that those government subsides also lowered mortgage lending standards and resulted in increasing numbers of delinquencies (Wallison, 2009). As expected, those defaults diminished the assets of the population, and paved the way for a recession. John Taylor in his endeavor to explain what went wrong in pre-2007 period, argued that series of government actions and interventions paved the way for the crisis and also prolonged it.

According to Taylor, first mistake was treasury's unusually loose monetary policy and loose housing credit guarantees of government agencies like Freddie Mac and Fannie Mae. After the housing boom, Federal Reserve Bank misdiagnosed the problem as liquidity crisis, instead of an uncertainty crisis regarding the value of sub-prime assets. Resulting ad-hoc bail-out packages in mid-2008 and unpredictable terms of the TARP legislation created sharp rises in market uncertainties (Taylor, 2009). For Jeffrey Friedman, the resultant crisis after 2008 was the crisis of politics rather than finance as decades long attempts to create hybrid capitalism through web of regulations failed in 2007. He blamed the government's certain actions and inactions throughout the prior decade, as government intervention into housing markets through its sponsored agencies distort market signals and opened way for moral hazard behavior since most actors did not know the precise role of regulations and its limits over the housing market (Friedman, 2009).

On a different note, Alan Greenspan blamed the emergence of the crisis on the formation of what he called 'irrational exuberance' among banks and investors pertaining to house and related assets prices, which spurred excessive risk-taking on the part of market actors. For example, Ivashina 
and Scharfestein pointed out how the widespread and reckless short-term credits to borrowers before the housing price bubble burst made banks vulnerable to bank runs and as an extension, that behavior largely froze up the credit markets during the crisis (Ivashina and Scharfestein, 2010). That behavior was also supported by bank's increasing reliance on off-balance sheets in dealing with securitized mortgages followed by lax regulation of off-balance sheet operations that predictably decreased the capital reserves of subject banks. (Acharya and Richardson, 2009) In the same strand, Erkens and Hung argued that increasingly risky investment strategies undertaken by financial firms and banks prior to crisis stemmed from short-term incentives of shareholders and their disproportionate leverage over the managers of those firms. On the other side, they added that firms with management who were more independent from shareholder pressure were more cautious, thus delved into sub-prime market less. So, one of the most important causes of the crisis was the failed risk management strategies of financial and banking companies. (Erkens, Hung and Matos, 2012; Brunnermeier, 2009). William W. Lang and J. Jagtiani saw the problem as linked to failing risk management strategies of banks and financial institutions, relying on untested risk models which failed to correctly predict the housing downturn (Lang and Jagtiani, 2010).

At worst, in mainstream economics, these repeated bust and boom cycles were interpreted as a common occurrence in the system, a sort of business cycle. Some even argued that these cycles turn out to be useful in the end, since they cleanse the market of unproductive capital and idle capacity. Thus, neo-liberal economists sought out the causes of the crisis in symptoms of capitalist-social relationships. For example, any acceptance of the Hayekian assumption that market prices usually give consumers the best possible information is clearly contradicted by banks' failed risk management strategies. Without any inherent fault in the operation of markets, how could this phenomenon of 'irrational exuberance' ride roughshod over people's common sense? Methodological individualism and bankers' sophisticated mathematical formulae did not provide sound risk management models, as these equations were incapable of questioning either the basic assumptions of their theory or the historical underpinnings of the rise and dominance of financial capital.

\section{Keynesians' View}

Although they did not want to fundamentally alter the nature of the market economy, Keynesian economists raised objections to certain assumptions of the laissez faire approach. First, they disputed the self-correcting equilibrium of demand and supply forces when faced with the anarchic features of markets and the role of human psychological expectations associated with the trajectory of markets. These uncertainties usually feed unemployment and unused capacities, since investors have no ability to correctly predict the perfect amount of investment that an economy needs at any specific time or in any specific place (Stiglitz, 1993). Beyond a threshold, lack of investment and resulting unemployment create recessions due to lack of demand, a situation which can return to full employment goal and sustainable growth only through monetary and 
fiscal intervention by an external source, namely the state (Keynes, 2006). Furthermore, since the days of J. Maynard Keynes, his intellectual followers have had no confidence in the credit and financial markets, since Keynes himself depicted them as casino- style institutions. Thus, they proposed close regulation of financial markets and investment banks. What we understand from these points regarding macro-economics is that Keynesians, through accepting basic promises such as the role of supply and demand, and priority of capital, do not see any inherent problem in the capitalist mode of production. Any associated faults with market economy can be corrected through sound management of aggregate demand, coupled with prudent financial regulation.

As is to be expected, prominent Keynesian economists differ greatly from the neo-liberal school, either in their diagnosis of what caused the Great Recession or the possible remedies for the main problems of the current economy. Paul Krugman from Princeton University was among notable experts who argued that the reason behind the 2008 crisis was the great majority's firm belief in the idea of efficient market hypothesis and its assumptions about the actions of rational investors in the market place. This efficient market thesis largely caused people and experts to overlook the underlying fundamental of economic activity and paved the way to a housing bubble (Krugman, 2009). Krugman further argued that by issuing derivatives and other products, unregulated financial actors like investment banks and hedge funds etc., perpetuated the expanding bubble. The sources needed for the bubble economy were coming from rising East Asian markets, who channeled their excess savings into the US market, coupled with the US federal reserve's low interest rate policy of $1 \%$ from the days of the 2001 recession. With the burst in the house price bubble, what lay revealed was the weaknesses of underlying assets, and the resulting reduction of value, to the tune of $13,000,000,000$ dollars, opened the way to huge indebtedness and collapse of demand. The effect of this was job losses of 6,000,000, with this rise in unemployment deepening recessionary tendencies in the real economy.

Other Keynesian economist emphasized different causes for the crisis, for Stiglitz, it was the deregulation of banking since 1980's and the increasingly risky behavior undertaken by financial institutions, such as replacing traditional, safe financial instruments (i.e. government bonds) with riskier assets like sub-prime mortgage derivatives that caused the recession after 2008 (Stiglitz,2009; Lewis, 2013). On other dimension Stiglitz also shared the views of post-Keynesian E. Stockhammer in terms of how rising inequality across advanced economies like US and UK created a demand gap between the rich and the poor. According to Stockhammer, declining share of wages in capitalist economies generally accompanied by rising share for the capital, which in turn feeds a speculative frenzy on risky assets. That situation gradually suppresses the consuming propensity of wage earning population and it eventually decreases the profit margins of firms as collapsing demand accelerated the slump. Banks' behavior of taking too much risk under those conditions only exacerbate the associated downturn as speculative money tends to flow towards financial and more profitable instruments (Stockhammer, 2013; Stiglitz, 2012).

As aforementioned authors pointed out Keynesian strand, like neo-liberals, do not see any inherent crisis tendencies in the capitalist system, they either stressed the deregulation and 
reckless behavior of banks or the lack of aggregate demand as main cause of the crisis. Thus, they argued that if these excessive tendencies are curbed through prudent oversight capitalism can return its normal growth path.

\section{Turkey: From Liberal Utopia to Keynesian Regulation}

In the final section of this paper, Turkey and its financial sector will be evaluated, as it constitutes a microcosm of these global discussions regarding the role of free markets and regulatory policies on potential crises. As stated above, regulatory reforms and supervision of the Turkish financial sector acted as a buffer to protect the country from the most harmful effects of the 2008 financial crisis, in contrast to the period of the late 90 s and early 2000s, when the country suffered deep financial and economic crisis within a relatively short interval. Even with the buffer in place though, the country has had to struggle with structural problems such as high unemployment, persistent inflation, volatile exchange rates and erratic current account balances, all left over from liberal deregulation policies of previous decades. This article now tries to argue that despite the success of Keynesian monetary and regulatory policies in preventing financial sector crisis, the inherent contradictory tendencies of capitalist economy have remained intact, and that Turkey is still standing on the brink of another economic crisis, the tendencies of which would be largely determined by external factors.

\section{From the 1980s to the 200 I Crisis}

Turkey's liberalization adventure began just like other underdeveloped countries in the immediate aftermath of the collapse of import substitution (ISM) policies and protected markets of peripheral Fordism. Turkey tried to sustain demand-led growth throughout the ' $60 \mathrm{~s}$ and '70s within controlled capital and exchange rate markets, but eventually reached the limits of this strategy when the country's manufacturing and agricultural exports could not bring in sufficient foreign exchange revenues to support the massive requirements of technology spending, infrastructure investments and intermediate capital imports to sustain the ISM strategy (Şenses and Taymaz, 2003). At the same time, rising labour wages and currency appreciation increased the political and economic demands of a rapidly-growing urban population, demands which were responded to hostilely by capital culminating in the September 1980 military coup (Boratav, 1988). That military coup did not just aim to stabilize the security situation in the country, but also to provide a convenient political arena in which to apply a neo-liberal economic stabilization program, a long-desired dream of the country's ruling classes. The resulting IMF-induced structural adjustment program envisaged large social spending cuts, a decrease in agricultural subsidies, trade liberalization, privatization, and gradual but significant depreciation of the currency. The most immediate effect on the banking sector was the lifting of restrictive Central Bank controls, resulting in the emergence of a plethora of private financial institutions collecting deposits from the population on the basis of a Ponzi finance scheme (Boratav,1988). When they 
collapsed around the mid ' 80 s, these groups treated the country to its first experience of a neoliberal savings crisis. This did not spread to the entire economy and the banks were allowed to open foreign currency deposit accounts and enter international transactions after 1984. When this gradual opening of the country's markets to the outside world did not bring the anticipated foreign direct investment, the country decided to engage in a full convertibility and adopt more convenient rules for in- and out-flows of capital. Retrospectively, the IMF- supported program's success in stabilizing the current account balance and reducing inflation was broadly dependent on the export boom of the mid ' 80 s, which in turn was sustained by a massive decline of the share of wage labor in the manufacturing sector (Savran, 2002). In addition, wages in the public and private sectors remained almost frozen throughout the $80 \mathrm{~s}$, thanks to the repressive labor and political legislation of the 1982 military junta constitution (Akyüz and Boratav, 2003). Labor's share of total revenues in manufacturing dropped to $20.6 \%$ in 1988 from $38 \%$ in 1977 . The next wave of trade liberalization in the ' 90 s was the dominant class response to declining profitability of the real sector, as the popular pressures of wage demands and requests for increasing freedom for political organizations mounted towards the end of 1989 (Akyüz and Boratav, 2003).

In the tumultuous years of the New World Order during the '90s, Turkey's full liberalization of capital movement was generally expected to bring foreign investment, which could help productive sectors that did not get enough capital because of Turkey's insufficient savings. However, these expectations remained unfulfilled, as neither the regulatory framework of the financial markets nor the general climate of world trade in terms of emerging markets favored positive outcomes for Turkey. In fact, most incoming foreign investments were in the form of portfolio investments (hot money) seeking short-term gains. Yeldan has argued that, rather than comforting the needs of industrial and manufacturing sector, these short-term money flows in and out of Turkey created an unhealthy cycle of dependence for the Turkish economy, in which the growth of inflows proportionally affected consumption and investment while outflows generally engendered high volatility in the exchange rate (Yeldan, 2001). The reason for this was a combination of two factors; growing public indebtedness under persistent high inflation paved the way for arbitrage gains for financial actors as the domestic real interest rates were substantially higher than those of developed markets, and the effects of persistent political instability in the country deriving from a plethora of social conflicts such as the Kurdish issue and unsustainable coalition governments whose average stay in power in the '90s was no more than 1 or 2 years (Yeldan, 2001). Also, in these years growing Islamic opposition and its contestation of the official discourse of Turkish secularism intensified these internecine conflicts in the state and ruling elites. Between 1991 and 2001, Turkey experienced four economic downturns and two of them, in 1994 and 2001, turned out to be severe financial crises. In fact, the downturns in '91, '94, ' 99 and 2001 all coincided with emerging market crises in the world economy and substantial outflows of foreign currency from the Turkish markets (Seyidoğlu, 2011).

So, in the shallow and volatile conditions of Turkish financial markets, the banking sector positioned itself as the government's main creditor, as successive administrations relieved public deficit problems under high inflation with an increase in the issue of treasury bills. Given 
opportunities for the arbitrage gains, banks usually chose to get credit from international markets and supply it to the treasury under excessively high interest rates (Güloğlu-Altınoğlu, 2002). This development further exacerbated Turkish banks' dependence on foreign currency and their vulnerabilities to any sudden negative developments in international markets. Any move by the government to lower the interest rates would have caused capital outflows, while the same high interest rates triggered inflationary pressures as the government resorted to printing money. For example, in 1994, the government had to guarantee all deposits in banks to prevent potential bank runs in the country. Eight Turkish banks were taken over by the Savings and Deposit Insurance Fund (SDIF) in the aftermath of 1994 currency crisis (Akyüz and Boratav, 2003).

As indicators of the health of the sector, foreign currency deposits were almost $43 \%$ of all deposits in 1999, while $75 \%$ of government tax revenues were diverted to repayment of maturing debt on treasury bills. Secondly, the Turkish banking sector ratio of transformation of deposits to credit was low during the decade. Total credits ratio to bank incomes fell from 69\% in 1990 to 38\% in 2000, which reveals the banking sector's main revenue source to be financing government debt. In those years, the latest research shows, banks had almost no risk management strategies in terms of their portfolio and lacked systematic regulation on that front. A further display of the disarray of the 1990s was the transfer of banking funds to parent corporations without any adequate credit supervision, a transfer facilitated by the lack of regulation in governments' issuing of new banking licenses (Akyüz and Boratav, 2003). Hence, in the 1990s, Turkey's real sector (manufacturing and industry) too were involved in the financing of government debt through excessively high interest rates by their banking associates. Just after the April 1994 currency crisis, the interest rate on treasury bills was around 150\% annually. Another corrupt activity in the country's banking and financial sector was shadowy methods of accounting that constantly ignored the effects of high inflation on real bank assets. In other words, throughout the 1990s, although Turkish banks seemed profitable businesses from the outside, their high operational costs and unregulated atmosphere of overall capital market lay in wait as potential triggers of crisis in the country (Öniş, 2003).

In the immediate aftermath of the 1997 Asian crisis, and turmoil in Russian financial markets a year on from that, in 1999 the Turkish economy faced another downturn, this time generally stemming from the lack of capital inflows to balance the financing needs of banks and the treasury. That economic recession forced the government to negotiate another structural adjustment loan with the IMF (Akyüz and Boratav, 2003). The main target of the agreement was to create an exchange rate-based disinflation program to stabilize competitiveness through appreciation of currency. Aside from that, the Central Bank was precluded from printing money against domestic assets. The remainder of the program was traditional IMF demands in terms of privatization, cuts in social spending etc. The first stage of the plan produced some positive results; T-bill interest rates decreased to $38 \%$ and capital inflows increased, which strengthened international reserves, even though $90 \%$ of the inflows were in form of portfolio investments (Yeldan, 2001). But, as a potential trigger of the eventual crisis, inflation turned out to be a messier issue than expected, since wage demands, increasing rents and rising commodity prices of state-owned enterprises fed 
inflationary expectations. In addition to this, newly-established rules of the program to control banking sector reserves and their open foreign currency position limits were never implemented effectively because the internal political, religious and social strife mentioned above prevented any sound and politically powerful management of the economy. The disarray in terms of power was very visible to the financial sector (Akyüz and Boratav, 2003).

In 2000, currency appreciation increased imports by 35\% while it spurred on exports by only $7 \%$. Turkey's current account deficit again reached 5\% of GDP. In November 2000, a speculative attack on the Turkish Lira stripped away the illusion of stability and the resulting sudden outflow of $\$ 5,200,000,000$ worsened the situation of domestic banks with large T-bill portfolios (Yeldan, 2001). These banks, among which the most notorious is Demirbank, tried to find emergency funds and thus increased overnight inter-bank rates. The stock market started to drop and the Central Bank tried to inject liquidity to the system (BDDK, 2009). But in February 2001, with the perfect excuse of a skirmish between the prime minister and president on the economy, a massive outflow of foreign currencies began as T-Bill interest rates shot up $70 \%$ and overnight interest rates climbed to $5000 \%$. With more than $\$ 17,000,000,000$ left the country, Central Bank had to left to defend the value of the currency and accepted free floating (BDDK, 2009). This financial crisis, while bankrupting a lot of private banks, cost the state around $\$ 53,000,000,000$ in solidifying the liquidity positions of these private and public banks. The country experienced a net $8.5 \%$ decrease in its GDP, with a $65 \%$ inflation rate. Total GNP dropped 33\%. The IMF provided the country with $\$ 18,000,000,000$ in total throughout 2001 , as unemployment doubled, with the addition of 1.5 million newly- unemployed, and industrial production almost came to a halt (Yeldan, 2001). The population's purchasing power also declined to almost two-thirds of pre-crisis levels. When the coalition government decided to call an early election at the end of the year, Turkey's experiment with the unregulated capital markets and banking sector reached its limits. Given IMF experiences during the Asian and other emerging market financial crises, it was obvious that the liberal utopia of the self-correcting market was an illusion and could no longer be continued in Turkey in its pure form.

\section{Post-200I Years, Turn to Regulation of Finance}

In the wake of this severe financial and economic crisis, the IMF and Turkish authorities agreed to submit management of the economy to technocrat Kemal Derviş, a veteran World Bank official, who declared an anti-inflationary re-stabilization program. Between 2001 and 2005 this program aimed first at a restructuring of the financial sector and liberalization, accompanied by regular neo-liberal targets such as increasing budget surplus after interest payments, raising indirect taxes, and reducing social spending (Öniş, 2003). Central Bank independence was strengthened, and with Law 4491, the Banking Regulatory and Supervision Agency (BRSA) was founded, with one of its functions being control of the deposit and savings insurance fund. Other regulatory agencies that were formed at the time were the Board of Competition, the Energy Market Regulation Board and the Public Bidding Board (Akyüz and Boratav, 2003). In the instigation 
of these changes, one may say that it was not only the failure of unfettered markets that played a role, criticisms of experts like Stiglitz, Krugman, and some people in the IMF of the precarious situation that unregulated capital movements engendered in the underdeveloped world also influenced events and decisions.

On the political side of management of the crisis, with the 2002 election victory of Islamist AKP (Justice and Development Party), Turkey's political landscape reached some kind of reconciliation among competing forces. While the secular metropolitan bourgeoisie accepted the legitimacy of an Islamist government, AKP in turn soothed reservations about itself by discarding much of the anti-western and radical economic rhetoric of its predecessor, the Welfare Party. On another plane, the political system stabilized in the absence of a strong Islamist opposition. Moreover, thirty years of a repressive labor regime pretty much crippled any organized working class resistance to the crisis or these new reform agendas. AKP also managed to anchor the country to the EU negotiation process and a new democratization process. IMF and EU support, coupled with the ongoing low interest rate policies of US Federal Reserve, benefited the country with an unprecedented glut of foreign funding. In terms of portfolio investments and foreign direct investment, Turkey surpassed all its previous records. We may argue that the same savings glut that Krugman saw as the reason for the 2008 financial crisis in the US helped Turkey to rebalance its economy in the aftermath of the 2001 crisis (Öniş, 2009).

\section{Banking Sector Reforms}

Immediately after the 2001 crisis, the newly-established BRSA began its job of restructuring. $28,700,000,000$ liras were transferred to public banks to strengthen their balance sheets, while their operational tasks in the sector were redefined in order to decrease political patronage (BDDK, 2009). Twenty-five private banks were transferred to DSIF with their assets and these banks were re-consolidated into six stronger banks. It emerged that most of these private banks vaults had been hollowed out by their major shareholders. BRSA decreased all bank branches to $33 \%$ of pre-crisis levels and at the same time increased bank branch supervisions (BDDK, 2009). It greatly increased supervisory agent numbers across the sector, while providing legal and technical support to bank managers. In terms of reforms of management, in addition to emphasizing risk management strategies and stress tests, BRSA made balance sheets and managements of banks more transparent. Licensing rules for the opening of new banks became much more restrictive (BDDK, 2009). Offshore banking was tied to strict BRSA supervision. Inflation adjusted accounting standards were adopted. Other regulatory reforms following these were supervision of credit enlargement within defined risk limits, forbidding the existence of outof-balance sheets funds, and transforming all derivative, swap, or future options transactions into credit transaction accountable to Central Bank reserve requirements (BDDK, 2009).

In the aftermath of the crisis years, the Turkish economy stabilized with the support of EU anchor, international support from institutions like the IMF and the WB, and because of the 
existence of relatively easy money that flowed into Turkey throughout the US housing boom years. Chinese and American quantitative easing policies after the 2008 crisis further contributed to the economic development of Turkey. Although there are numerous problems pertaining to this growth strategy, other than the crisis year of 2009, Turkish GDP numbers showed a stable pattern. Turkish interest rates, inflation numbers and credit growth have all displayed positive signs since 2002 (BDDK, 2009). The disinflationary program that aimed to suppress foreign exchange rates was a success, since inflation dropped to single digits after 2005 from over $30 \%$ in 2002. This event, coupled with the political stability of these years, (Turkish public debt ratio to GDP decreased to 39\%) created the perception among the public that the rule of AKP was the sole reason for these positive developments (Kibritçioğlu, 2007).

Even after the 2008 crisis, in the banking sector we see a sound financial industry, especially compared to Western banks. Turkish bank numbers and their branches have been reduced and employment turnovers stabilized, the transformation of deposits to credit has quickened, while the share of credits in total transactions of banks increased to $50 \%$ during these years. Profitability rates of the financial sector have been reinvigorated, from minus levels in 2001 to $12 \%$ in 2005 (BDDK,2009). Also, due to strict BRSA regulations on derivatives and Turkish banks' offshore fund transactions, the country's banking system did not involve itself in either credit swaps or sub-prime mortgage markets throughout the booming period of these debt instruments. Two other positive issues that protected Turkish banking from harmful effects of the crisis were the relatively modest ratio of foreign currency debts of the country's banks, and the higher capital adequacy ratio of Turkish banks, which was around 18\%, compared to 11-12\% rate of European banks. Then one may assert that the Keynesian-style macro-economic regulations of the financial sector yielded good results, and potentially saved the country from the turmoil of another potential crisis during the 2008-09 disaster (Öniş, 2009).

So, the remaining question is whether these partial regulatory policies of Keynesianism in the financial sector have mostly eradicated the potential sources of crisis in the Turkish economy. In the last part, I will try to show that the answer is no, and that the country could be brought to a brink of a crisis at any time due to the structural problems inherent in capitalist growth.

\section{Potential Triggers for Crisis}

The important problematic issue for the Turkish economy and its current growth strategy is currency appreciation. In a disinflationary program that chooses the exchange rate as the nominal anchor, exchange rate stability is a sign to potential investors that the country is a good place for investment. However, the Turkish lira began to appreciate against foreign currencies immediately after the program's implementation and as a result, in 2004 Turkish imports of consumption goods skyrocketed, with $108 \%$ annual growth accompanied by a current account deficit problem (Trading Economics, 2014). Since 2002, trends in the increase and decrease of current deficit numbers were positively correlated with those of import growth. For example, in 2009, when 
the global crisis and outflow of funds from Turkey negatively affected economic growth, Turkish imports registered a sharp decline. Another controversial point regarding currency appreciation is its impact on domestic industries' competitiveness. Uras wrote that Turkish industry and manufacturing is greatly dependent on intermediate commodity import. Value added numbers show that in big industrial branches like auto and machinery production, every 100 TL worth of goods involved around 88 TL imported value (Uras, 2014) Therefore Turkish manufacturing has a very low base of added value in production, which may cripple efforts to break this vicious circle between rising growth and rising current deficits. Turkey's current deficit ratio to GDP is just behind that of crisis-torn Greece in the OECD. In the same research, it was noted that only $3.7 \%$ of Turkish exports involved high technology production, while the same number for the European average is around $19 \%$ (Uras, 2014).

These processes also reveal the tendency of cheap foreign goods to negatively affect Turkish employment. With its relatively low technology intensive and low value added manufacturing capacity, Turkey's employment distribution across different sectors is mainly concentrated in the service sector and agriculture, $35 \%$ and 23\% respectively (Sönmez, 2013). Industry and manufacturing's share in the distribution has been stagnant for the last decade, at around $16 \%$ of the work force. One may add the significant effect of IMF program privatization policies to these high unemployment patterns, since in the last three decades, the public sector has refrained from using its employment-creating power due to the ideological dominance of privatization within the economic establishment. These trends then largely explain why the Turkish unemployment rate has stubbornly fluctuated between around 10-12\% throughout the last decade (Sönmez, 2013). Even in high growth rate (9\%) years like 2011, the unemployment rate did not drop to under 9\%. If we couple Turkey's workforce participation rate of around 52\%, lower than most of its rivals, with a persistent $19-20 \%$ youth unemployment rate, it may be argued that this model of production and distribution patterns is pregnant with numerous social problems.

The last important issue in Turkey is the stubborn inflationary pressures that the country faces despite the so-called success of the last decade's disinflationary programs. Inflation, though it dropped to $5.2 \%$ around 2005, has shown itself to be a persistent feature in more recent years (Uras, 2014). Each time the country has entered a high growth pattern, inflation has ticked upward. One of the main reasons for this is the lack of savings and sources of investment within the country. Turkey's savings rate was around $12 \%$ in 2012, a figure substantially lower than the European average, so any additional need for foreign currency means an upward move for Turkish inflation (Colombo, 2014). For example, in just the first third of 2014, inflation reached $5 \%$ in total, largely as a result of the latest exchange rate rises. It is also easy to see that persistent inflation has brought with it skewed wealth distribution patterns, since the country is in the top three in terms of inequality index of OECD (OECD, 2014). Any potential economic crisis stemming from current deficit or external shocks that trigger higher inflation will also increase political and social instability in Turkey. Hence, the three related issues of current deficit, high unemployment and sticky inflation run as a thread through economic life in Turkey, and are 
still with us as potential sources of crisis in an external shock situation. The financial and partial regulatory policies of Keynesians have so far failed to totally eradicate them.

Also on the issue of politics and its relationship with economy in the country, Rodrik argued that AKP governments alleged accomplishments like huge per capita growth rates after 2003 is largely a myth since any consideration of inflation adjusted per capita income growth rates indicated only \%46, which was dismal compared to other emerging market statistics (Brazil, India, Russia, Poland). So according to Rodrik, Turkey could not even use those chances of savings glut just before the 2008 financial crisis as most of those foreign flows diverted to construction and other low value added sectors and could not radically alter the production patterns of the country (Rodrik, 2015).

On a different take, Buğra and Bedirhanoğlu argued that gradually the difference between modern bourgeois form of state and the AKP rule has been emerging as the Erdoğan and his circle increasingly resort to politics of clientelism in distribution of state resources. For example, the regulations that design the public procurement and bidding processes were changed more than hundred times during party's rule (Buğra, 2015). Buğra further added that this soaring symbiosis between the part of the private sector and the AKP created what she called a rift between what big industrialist groups like TUSİAD envisioned when they supported the party's neo-liberal agenda earlier and the supposed Islamization of politics that those close to Erdogan's inner circle demands. Bedirhanoglu thought that the religion became a means or a convenient tool in continuation of this clientelistic link (Bedirhanoğlu, 2015). It seems like these two authors agreed that typical bourgeois rule demand a more autonomous sphere for economic activity and state should be more neutral towards the competing social groups under Turkish neo-liberalism. EU agenda of the ruling circles in mid-2000's largely planned a more technocratic management of economy and fast adaptation to EU standards. But in these days AKP and Erdogan's personal style which reduces the independence of judiciary and press, and vocal calls for an end to parliamentary system rendered the country more vulnerable to political and economic shocks as the country's growth strategy depends on the continuous flow of foreign funds. So, the events of last three four years did not help to promote the stability picture that the ruling party tried to create

\section{Conclusion}

In the wake of the 2008 Great Recession, the main pundits of political economy did not, as expected, engage in any ontological and historical critique of the dominant relationships, but tended to confine the controversy to the liberal-Keynesian framework. However, this framework, while revealing the insufficiency of markets in controlling the excesses of financial actors, has failed to find a proper long-term stabilizer for the future of capitalism

As a microcosm of that dispute, my research on the Turkish financial sector drew comparisons between two financial crises, 2001 and 2008. This research clarifies the fact that Keynesian 
policies of government intervention in and regulation of financial activities were superior to the almost utopian attitudes of neo-liberals. The Turkish economy and financial sector entered the 2001 crisis as a result of almost entirely free and unregulated markets, and turned to Keynesianstyle regulatory policies immediately afterwards to repair the destruction done. Therefore, the almost intact and unscathed condition of the country's financial system after the 2008 global crisis surely points to the aforementioned superiority of the Keynesian method.

However, in the final analysis, and despite initial success, years after the 2008 crisis the Turkish economy and society are still in the grip of structural problems of capitalist markets. As recounted above, these are chronic high unemployment, vast current account deficits and its associated problems in foreign exchange parities, and persistent inflation. These factors may be triggers for a social or economic crisis at any time and render the country especially vulnerable to external shocks originating in international markets. Hence, it is obvious that Keynesian solutions are not enough to make the system crisis-free. What they fail to consider is that the capitalist mode of production is structurally embedded in the social relations of respective societies, i.e. they fail to see that it is futile to separate economics from politics. Without an ontological and historical critique of our present system, as Marx and Polanyi undertook in earlier times, we cannot find definite answers to the crisis-prone nature of market economy. Thus, there is an international need for a radical alternative as a potential solution, although the feasibility of such an alternative greatly depends on the deliberation and conscious intervention of human societies into our history. 


\section{References}

Acharya, V. \& Richardson, M. (2009). "Causes of the financial crisis". Critical Review, 21(2-3), 195-210.

Akyüz, Y. \& Boratav, K. (2003). “The making of the Turkish financial crisis”. World Development, 31(9), 1549-1566.

Balkan, N. and Savran, S. ed., (2002). The Ravages of Neo-liberalism: Economy, Society, and Gender in Turkey. New York: Nova Publishers.

Bankacıllk Düzenleme ve Denetleme Kurulu (2009). Krizden İstikrara Türkiye Tecrübesi. [online] Ankara: BDDK Döküman Merkezi.

Available at: http://www.bddk.org.tr/websitesi/turkce/raporlar/calisma_raporlari/7378krizden\%20 \%C4\%B0stikrara\%20t\%C3\%BCrkiye\%20tecr\%C3\%BCbesi.pdf

Bedirhanoğlu, P. (2015), "Corruption and State under the AKP Rule in Turkey: Retreat from the Modern Bourgeois State?" Centre for Policy Analysis and Research on Turkey, 4 (5) pp.35-44.

Available at: http://researchturkey.org/?p=8817

Boratav, K. (1988). Türkiye İktisat Tarihi, 1908-1985 (Vol. 1). İstanbul: Gerçek Yayınevi.

Colombo, J. (2014). Why the Worst Is Still Ahead for Turkey's Bubble Economy. [online] Forbes.

Available at: https://www.forbes.com/sites/jessecolombo/2014/03/05/why-the-worst-is-still-ahead-forturkeys-bubble-economy/\#79e924794145 [Accessed 15 May 2015].

Brunnermeier, M. \& Pedersen, H. (2009). "Market liquidity and funding liquidity". Review of Financial Studies, 22(6), 2201-2238.

Buğra, A. (2015). Prof. Dr. Ayşe Buğra: Türkiye’de bugün din, ekonomik modelin ilişki sermayesi. [online] T24.

Available at: http://t24.com.tr/haber/prof-dr-ayse-bugra-turkiyede-bugun-din-ekonomik-modelin-iliskisermayesi,287342 [Accessed 15 May 2015].

Erkens, D., Hung, M. \& Matos, P. (2012). “Corporate governance in the 2007-2008 financial crisis: Evidence from financial institutions worldwide". Journal of Corporate Finance, 18(2), 389-411.

Friedman, J. (2009). "A crisis of politics, not economics: complexity, ignorance, and policy failure". Critical Review, 21(2-3), 127-183.

Güloğlu, B. \& Altunoğlu, E. (2002). "Finansal Serbestleşme Politikaları ve Finansal Krizler: Latin Amerika, Meksika, Asya ve Türkiye Krizleri”. İstanbul Üniversitesi Siyasal Bilgiler Fakültesi Dergisi, 27, 111140.

Ivashina, V. \& Scharfstein, D. (2010). "Bank lending during the financial crisis of 2008”. Journal of Financial Economics, 97(3), 319-338.

Keynes, J.M. (1925). “Am I a Liberal”, The Collected Writings of John Maynard Keynes, Vol 9. London: St Martin's Press.

Keynes, J.M. (1963). Essays in Persuasion. London: WW Norton \&Company

Keynes, J. M. (2006). General theory of employment, interest and money. New Delhi: Atlantic Publishers \& Dist.

Kibritçioğlu, A. (2007). Türkiye’deki Hükümetlerin Makroekonomik Performanslarının Bir Karşılaştırması, 1987-2007. MPRA Paper No: 3962. [online] Munich Personal RePEc Archive.

Available at: https://mpra.ub.uni-muenchen.de/3962/1/MPRA_paper_3962.pdf [Accessed 15 May 2015].

Krugman, P. (2009). Revenge of the Glut. [online] New York Times.

Available at: http://www.nytimes.com/2009/03/02/opinion/02krugman.html [Accessed 15 May 2015].

Lang, W. \& Jagtiani, J. (2010). “The mortgage and financial crises: The role of credit risk management and corporate governance". Atlantic Economic Journal, 38(3), 295-316. 
OECD (2014). World Outlook Report.

Available at: http://www.oecd.org/eco/outlook/economicoutlook.htm [Accessed 15 May 2015].

Öniş, Z. (2003). "Domestic Politics versus Global Dynamics: Towards a Political Economy of the 2000 and 2001 Financial Crises in Turkey”. Turkish Studies, 4(2), 1-30.

Öniş, Z. (2009). "Beyond the 2001 financial crisis: The political economy of the new phase of neo-liberal restructuring in Turkey". Review of International Political Economy, 16(3), 409-432.

Rodrik, D. (2017). Turkish economic myths. [Blog] Dani Rodrik's weblog: Unconventional thoughts on economic development and globalization.

Available at: http://rodrik.typepad.com/dani_rodriks_weblog/2015/04/turkish-economic-myths.html [Accessed 15 May 2015].

Polanyi, K. (1944). The Great Transformation: the political and economic origins of our time, Boston: Beacon Press.

Şenses, F. \& Taymaz, E. (2003). "Unutulan bir toplumsal amaç: Sanayileşme ne oluyor? Ne olmalı? In Köse A., Şenses F. and Yeldan E. (eds.), İktisadi Kalkınma Kriz ve İstikrar, İstanbul: İletişim.

Seyidoğlu, H. (2003). "Uluslararası mali krizler, IMF politikaları, az gelişmiş ülkeler, Türkiye ve dönüşüm ekonomileri”. Doğuş Üniversitesi Dergisi, 4 (2)

Available at: http://openaccess.dogus.edu.tr:8080/xmlui/handle/11376/537 [Accessed 15 May 2015].

Skidelsky R. (1992) John Maynard Keynes: Volume 2: The Economist as a Saviour, 1920-1937. New York: Penguin.

Sönmez, M. (2013). Gerçek işsizlik yüzde 20, işsizler 6 milyon!.... [Blog]Mustafa Sönmez.

Available at: http://mustafasonmez.net/?p=3879 [Accessed 15 May 2015].

Stiglitz, J. (2000). The Insider. [online] New Republic.

Available at: https://newrepublic.com/article/61082/the-insider [Accessed 15 May 2015].

Stiglitz, J. (2009). The financial crisis of 2007-2008 and its macroeconomic consequences. [PDF]

Available at: http://unpan1.un.org/intradoc/groups/public/documents/apcity/unpan033508.pdf [Accessed 15 May 2015].

Stiglitz, J. (2012). The Price of Inequality: How Today's Divided Society Endangers Our Future. London: Penguin UK.

Stockhammer, E. (2013). "Rising inequality as a cause of the present crisis". Cambridge Journal of Economics, 39 (3), 935-958.

Taylor, J. B. (2009). Economic policy and the financial crisis: an empirical analysis of what went wrong. Critical Review, 21(2-3), 341-364.

Trading Economics. (2014). Turkey Current Account to GDP. [online] Available at: https://tradingeconomics. com/turkey/current-account-to-gdp [Accessed 15 May 2015].

Uras, G. (2014). Satılan her 100 otoda yerlinin payı 33’ten 25’e düştü... Milliyet. [online]

Available at: http://www.milliyet.com.tr/satilan-her-100-otoda-yerlinin/ekonomi/ydetay/1849141/default. htm [Accessed 15 May 2015].

Yeldan, E. (2001). On the IMF-Directed Disinflation Program in Turkey: A Program for Stabilization and Austerity or a Recipe for Impoverishment and Financial Chaos? Available at: http://www. networkideas.org/featart/dec2001/Erinc_Yeldan.pdf [Accessed 15 May 2015]. 